\title{
Penerapan Metode Think Pair Share untuk Meningkatkan Prestasi Belajar Materi Peran Serta dalam Pemilihan Organisasi di Sekolah pada Siswa Kelas V SD
}

\author{
Mestiyah $^{1}$ \\ ${ }^{1}$ SDN 2 Banyuurip, Kalidawir, Tulungagung \\ Email: ${ }^{1}$ mestiyah_banyuurip@gmail.com
}

\begin{tabular}{l}
\hline Tersedia Online di \\
\hline http://www.jurnal.unublitar.ac.id/ \\
index.php/briliant \\
\hline \\
\hline Sejarah Artikel \\
Diterima pada 11 Februari 2018 \\
Disetuji pada 11 Februari 2018 \\
Dipublikasikan pada 13 Februari \\
2018 Hal. 80-91 \\
\hline
\end{tabular}

\section{Kata Kunci:}

think pair share, prestasi belajar, peran serta dalam organisasi,

\section{DOI:}

http://dx.doi.org/10.28926/briliant .v3i1.143

\begin{abstract}
Abstrak: Berdasarkan hasil observasi yang dilakukan di Kelas VA pada waktu pembelajaran Pendidikan Kewarganegaraan diperoleh hasil bahwa Prestasi belajar siswa kurang memuaskan, yaitu dari 24 siswa hanya 10 siswa yang nilainya dapat mencapai $\mathrm{KKM}$ atau $\geq 70$, sedangkan 14 siswa lainnya masih belum dapat mencapai KKM atau $\leq 69$. Hal ini disebabkan karena guru kurang memberikan penekanan materi yang jelas tentang Peran serta dalam pemilihan organisasi di sekolah. Untuk itu agar dapat meningkatkan prestasi belajar siswa dalam menyelesaikan soal tentang Peran serta dalam pemilihan organisasi di sekolah serta untuk tercapainya tujuan pembelajaran perlu diadakan perbaikan pembelajaran dengan menerapkan Metode Think Pair Share. Penerapan pembelajaran Peran serta dalam pemilihan organisasi di sekolah melalui Metode Think Pair Share dapat meningkatkan Prestasi belajar siswa Kelas VA SD Negeri 2 Banyuurip Kalidawir Tulungagung
\end{abstract}

Menurut Kerr (Winataputra \& Budimansyah, 2007: 4), pendidikan kewarganegaraan dirumuskan secara luas untuk mencakup proses penyiapan generasi muda untuk mengambil peran dan tanggung jawab sebagai warganegara, dan secara khusus, peran pendidikan termasuk di dalamnya persekolahan, pengajaran dan belajar, dalam proses penyiapan warganegara tersebut. Pendidikan kewarganegaraan dirumuskan secara luas untuk mencakup proses penyiapan generasi muda untuk mengambil peran dan tanggung jawab sebagai warganegara, dan secara khusus, peran pendidikan termasuk di dalamnya persekolahan, pengajaran dan belajar, dalam proses penyiapan warganegara tersebut.

Menurut Branson (1997:7) tujuan Civic Education adalah partisipasi yang bermutu dan bertanggung jawab dalam kehidupan politik dan masyarakat baik tingkat lokal, negara, dan nasional.Pendidikan Kewarganegaraan di Indonesia dapat diharapkan mempersiapkan peserta didik menjadi warga negara yang memiliki komitmen yang kuat dan konsisten untuk mempertahankan Negara Kesatuan Republik Indonesia. Hakikat negara kesatuan republik Indonesia adalah negara kesatuan modern. Negara kebangsaan adalah negara yang pembentuknya didasarkan pada pembentukan semangat kebangsaan dan nasionalisme yaitu pada tekad suatu masyarakt untuk membangun masa depan bersama dibawah satu negara yang sama, walaupun warga masyarakaat itu berbeda-beda agama, ras, etnik, atau golongannya. 
Dalam proses pembelajaran di kelas sering timbul masalah yang pada umumnya dialami oleh siswa. Masalah yang dihadapi siswa bersifat unik berbeda satu sama lain. Misalnya masalah dan kesulitan ataupun rendahnya prestasi belajar yang dialami siswa pada mata pelajaran Pendidikan Kewarganegaraan bisa terjadi karena berbagai faktor diantaranya. (1) Keterbatasan kemampuan, keadaan, minat dan motivasi diri siswa itu sendiri. (2) Situasi belajar di sekolah atau kelas dan kurangnya sarana dan prasarana. (3) Materi pelajaran yang kurang relevan dengan kebutuhan siswa (4) Metode mengajar yang kurang bisa dipahami siswa bahkan kurangnya alat peraga dan alat bantu mengajar.

Apalagi mata pelajaran Pendidikan Kewarganegaraan menuntut kemampuan Guru untuk bisa membuat siswa mengerti dan memahami tentang materi yang diajarkan dengan tidak hanya membaca buku dan teori saja melainkan harus diterapkan dalam kehidupan sehari-hari, bermasyarakat dan berdaulat, agar siswa memiliki pengetahuan, keterampilan yang cerdas, terampil, berkarakter yang diamanatkan oleh Pancasila dan UUD 1945.

Berdasarkan hasil pengamatan dalam proses belajar mengajar dikelas, keadaan sekolah, dan melalui peninjauan bidang akademik dan non akademik, diperoleh hasil bahwa keadaan Sekolah Dasar Negeri 2 Banyuurip Kalidawir khususnya siswa kelas VA tahun ajaran 2015/2016 dalam pelajaran Pendidikan Kewarganegaraan belum menunjukkan prestasi belajar sesuai dengan KKM yang ditetapkan terutama pada peran serta dalam pemilihan organisasi di sekolah. Padahal, ditinjau dari keadaan fisik sekolah, yaitu ruang kelas VA sudah baik dan sesuai sebagai tempat berlangsungnya proses belajar mengajar. Pengamatan pada proses pembelajaran oleh peneliti dapat disimpulkan bahwa pelaksanaan proses belajar mengajar lah yang belum membuat siswa aktif belajar, sehingga kemampuan siswa belum tergali dengan maksimal.

Menurut Buchori (1997: 85) prestasi adalah hasil yang berupa angka, huruf serta tindakan hasil belajar yang berupa angka atau hasil karya yang dicapai juga dapat untuk memotivasi agar prestasinya lebih meningkat. Prestasi juga dapat diartikan hasil yang diperoleh karena adanya aktifitas belajar yang dilakukan. Seorang siswa yang mempunyai nilai akademik maupun non akademik dibanding teman-temannya bisa kita sebut siswa berprestasi. Dari uraian di atas dapat diketahui bahwa prestasi adalah hasil yang dicapai karena adanya aktifitas dan usaha yang sungguh-sungguh dalam belajar yang dinyatakan dalam angka atau huruf.

Menurut Sudjana (1989:28) belajar adalah proses yang diarahkan kepada tujuan, proses berbuat melalui berbagai pengalaman, melihat, mengamati dan memahami sesuatu. Hamalik (1999:37) berpendapat belajar adalah suatu proses perubahan tingkah laku siswa melalui interaksi dengan lingkungan.Pada ulangan harian Pendidikan Kewarganegaraan dengan peran serta dalam pemilihan organisasi di sekolah, di dapat rata-rata nilai sebesar 58,3\% dari 24 siswa, padahal Kriteria Ketuntasan Minimalnya (KKM) telah ditentukan nilai sebesar 70. Dan hanya 10 siswa yang mendapat nilai di atas 70 . Hal ini berarti, hanya $41,7 \%$ dari siswa yang telah mencapai ketuntasan belajar, dan yang lainnya memiliki prestasi belajar yang rendah.

Berdasarkan hal tersebut, peneliti meminta bantuan kepada teman sejawat untuk meneliti kekurangan dari pembelajaran yang telah dilaksanakan. Dari hasil diskusi dengan teman sejawat ditemukan masalah-masalah dalam proses 
pembelajaran Pendidikan Kewarganegaraan yang menyebabkan menurunkan prestasi belajar adalah sebagai berikut: (1) Materi kurang dapat dikuasi siswa secara optimal. (2) Siswa belum dapat menyelesaikan soal peran serta dalam pemilihan organisasi di sekolah. (3) Melihat hasil ulangan harian siswa diatas, bisa dilihat jika penggunaan metode pembelajaran dalam pembelajaran Pendidikan Kewarganegaraan pada siswa kelas VA belum sesuai dan membuat siswa terlihat tidak antusias untuk belajar. Pembelajaran dengan metode konvensional yaitu dengan menjelaskan materi dan siswa hanya melakukan perintah mengerjakan soal tanpa penanaman konsep pembelajaran yang kuat ternyata tidak efektif dalam proses peningkatan prestasi belajar siswa.

Oleh karena itu, demi memperbaiki berbagai masalah yang ada, peneliti memerlukan suatu solusi untuk mengatasi hambatan-hambatan yang terjadi. Akhirnya diputuskan dengan menggunakan Metode think pair share dalam pembelajaran Pendidikan Kewarganegaraan ini. Think Pair Share merupakan jenis pembelajaran kooperatif yang dirancang untuk mempengaruhi pola interaksi siswa. Think Pair Share menghendaki siswa bekerja saling membantu dalam kelompok kecil (2-6 anggota) dan lebih dirincikan oleh penghargaan kooperatif, dari pada penghargaan individual (Ibrahim dkk: 2000: 3).

Penerapan model pembelajaran think pair share dapat mengembangkan keterampilan berfikir dan menjawab dalam komunikasi antara satu dengan yang lain, serta bekerja saling membantu dalam kelompok kecil. Hal ini sesuai dengan pengertian dari model pembelajaran Think-Pair-Share itu sendiri, sebagaimana yang dikemukakan oleh Lie (2002: 57) bahwa, Think-Pair-Share adalah pembelajaran yang memberi siswa kesempatan untuk bekerja sendiri dan bekerjasama dengan orang lain. Dalam hal ini, guru sangat berperan penting untuk membimbing siswa melakukan diskusi, sehingga terciptanya suasana belajar yang lebih hidup, aktif, kreatif, efektif dan menyenangkan.

.Sehingga, tujuan dari penelitian ini adalah untuk mengetahui (1) bagaimana penerapan metode think pair share untuk meningkatkan prestasi belajar siswa kelas $\mathrm{V}$ pada materi peran serta dalam pemilihan organisasi di sekolah. (2) apakah metode think pair share dapat meningkatkan prestasi belajar siswa kelas $\mathrm{V}$ pada materi peran serta dalam pemilihan organisasi di sekolah.

\section{METODE}

Penelitian tindakan sekolah ini dilaksanakan di ruang kelas VA Sekolah Dasar Negeri 2 Banyuurip Kalidawir Tulungagung Tahun Pelajaran 2015/2016. pada semester 2, pada tanggal 9 Maret 2016 sampai dengan 16 Maret 2016. waktu yang diperlukan 2 x 35 menit. Dalam penelitian ini subjek yang digunakan adalah adalah seluruh siswa kelas VA Sekolah Dasar Negeri 2 Banyuurip Kalidawir Tulungagung tahun pelajaran 2015/2016 sebanyak 24 siswa yang terdiri dari 7 siswa putra dan 17 siswa putri.

Penelitian ini (PTK) dilakukan dengan dua siklus, dimana masing-masing siklus dikenai perlakuan yang sejenis dengan bobot yang beda. Dibuat dua siklus dimaksudkan untuk memperbaiki system pengajaran yang dilaksanakan. 


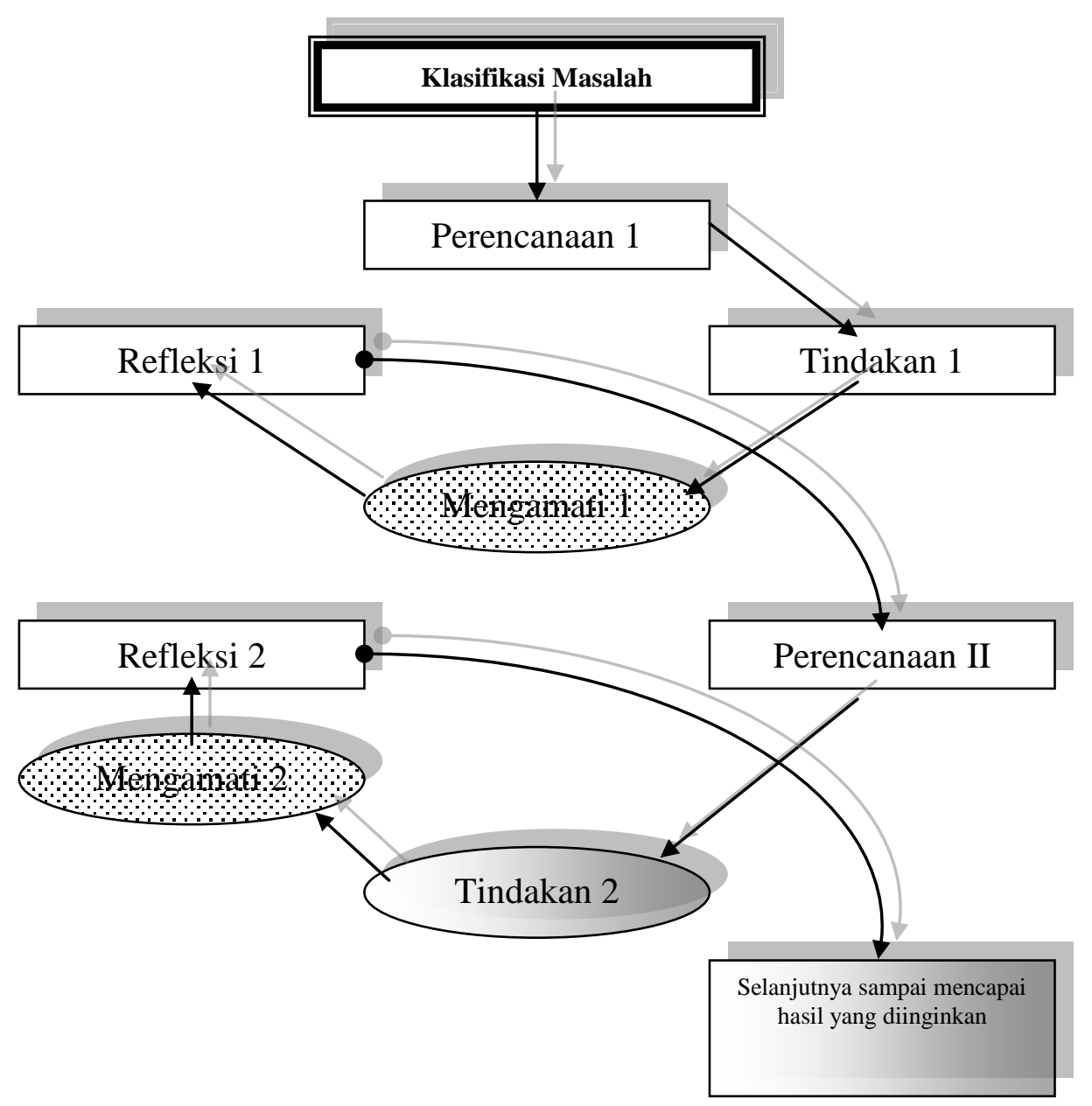

Gambar 1 Langkah-Langkah PTK dengan 2 Siklus

Adapun ragam instrument penelitian tindakan kelas yang telah dipersiapkan yaitu, Rencana Pelaksaaan Pembelajaran sebagai instrument rencana pelaksanaan tindakan. Lembar observasi Guru sebagai instrument utama pengumpul data proses dan lembar observasi siswa, wawancara, angket dan catatan lapangan sebagai instrument pendukung pengumpul data proses. Selain itu juga terdapat instrument pengumpul data hasil, yang dapat dikumpulkan dari hasil belajar berdasarkan soal-soal yang diberikan, serta ketrampilan siswa berdasarkan rubrik yang ada.

Teknik analisis yang digunakan yaitu deskriptif persentase. Data hasil penelitian yang dianalisis meliputi rata-rata kelas, ketuntasan belajar individu dan ketuntasan belajar secara klasikal. Selanjutnya hasil analisis data diperoleh baik secara kualitatif (dengan kata-kata) dan kuantitatif (dengan grafik). Hasil ini diinterprestasikan dan disimpulkan untuk menjawab permasalahan yang ada. Analisis data dari sumber-sumber informasi hasil penelitian di dapat dari: (1) Analisis dara observasi, Data hasil observasi keterlaksanaan pembelajaran melalui Metode think pair share dan observasi aktivitas siswa dianalisis secara deskriptif untuk memberikan gambaran pelaksanaan pembelajaran dengan menggunakan Metode think pair. (2) analisis data wawancara, Hasil wawancara dengan siswa dianalisi secara deskriptif dengan lembar angket untuk mengetahui pendapat Guru dan siswa terhadap pembelajaran dan (3) analisis data tes. 


\section{HASIL}

\section{Siklus I}

\section{Observaasi Kegiatan Siswa}

Kegiatan observasi dilaksanakan saat proses pembelajaran Pendidikan Kewarganegaraan berlangsung. Kegiatan observasi difokuskan pada pelaksanaan pembelajaran. Dalam kegiatan ini, Guru mengamati jalannya pembelajaran. Pertama-tama Guru memberikan penjelasan, instruksi atau pertanyaan terhadap peran serta dalam pemilihan organisasi di sekolah dalam bentuk soal. Kedua, Guru mengamati langkah-langkah kegiatan siswa ketika melaksanakan percobaan, sudah sesuaikah langkah yang ditempuh siswa dengan langkah-langkah yang tertera dalam lembar kegiatan. Hasilnya, masih ada kelompok yang terlihat bingung dalam pelaksanaannya, ada yang kurang teliti, ada pula yang bingung dengan langkah yang harus dilaksanakan. Ketiga, Guru mengamati keaktifan siswa saat melaksanakan percobaan, ada beberapa siswa yang tidak aktif dalam melaksanakan percobaan, siswa tersebut hanya berdiam diri, seolah-olah tidak mau tahu.

Pengamatan selanjutnya, Guru mengamati bagaimana keaktifan siswa ketika berdiskusi untuk menarik simpulan, ada beberapa siswa yang aktif berargumen dan ada yang berdiam diri saja. Pengamatan yang paling akhir adalah bagaimana kesimpulan hasil diskusi siswa, apakah sesuai dengan hasil pelaksanaan percobaan atau tidak. Dari pengamatan yang terakhir ini ada tiga kelompok yang belum berani mempresentasikan hasil temuan, dan hanya terdapat 3 (tiga) siswa yang mau mengajukan pertanyaan. Hal ini disebabkan, kurangnya petujuk dan bimbingan dari Guru.

Dari uraian di atas dapat disimpulkan hasil observasi dari siklus I antara lain Sebagian besar siswa mengerjakan tugas secara berkelompok dengan antusias. Sebagian besar siswa terlibat aktif dalam pembelajaran dengan menggunakan Metode think pair share. Sebagian besar siswa sudah memperhatikan penjelasan Guru. Hanya ada 5 siswa yang tidak memperhatikan, mereka justru mengajak bicara dengan teman sebangkunya. Sebagian besar siswa sudah dapat memahami lembar kegiatan dengan baik, hanya terdapat 5 siswa yang masih bertanya pada Guru tentang peran serta dalam pemilihan organisasi di sekolah. Baru terdapat sebagian kecil siswa yang ikut ambil bagian dalam diskusi kelompok. Sebagian besar siswa justru saling berbincang dengan teman duduknya. Terdapat 3 (tiga) kelompok yang melaksanakan diskusi dengan sungguh-sungguh. Dari 3 (tiga) kelompok, baru terdapat 1 (satu) kelompok yang sudah dapat menyelesaikan Lembar Kegiatan dengan tepat waktu. Sedangkan 2 (dua) kelompok yang lain membutuhkan waktu lebih dari 20 menit. Dari 3 (tiga) kelompok, baru ada 1 (satu) kelompok yang sudah berani mempresentasikan hasil temuan kelompoknya, sedangkan 2 (dua) kelompok yang lain belum berani

Metode pembelajaran dengan memberikan tugas kepada peserta didik untuk berdiskusi dengan teman kelompok menjelaskan perlunya sekolah memiliki organisasi terlihat kurang efektif. Karena terlihat beberapa siswa masih banyak siswa yang tidak membantu teman kelompoknya dan hanya bermain-main, sehingga waktu yang dialokasikan dalam pembelajaran kurang terlaksana dengan baik.Sewaktu presentasi hasil kelompok dilakukan, hanya terdapat 3 (tiga) siswa yang mau mengajukan pertanyaan. Sehingga dapat disimpulkan jika siswa kurang 
maksimal dalam menyerap konsep yang diajarkan. Masih ada beberapa siswa yang masih tampak bingung dalam melaksanakan kegiatan pembelajaran.

\section{Observaasi Kegiatan Guru}

Melaksanakan pembelajaran sesuai dengan rencana pembelajaran yang telah disusun. Guru membuka pelajaran dengan baik, mengabsen siswa dan menyampaikan tujuan pembelajaran. Menjelaskan tentang pembelajaran dengan Metode think pair share. Karena masih baru di perkenalkan oleh siswa, beberapa siswa masih tampak bingung. Mengamati jalannya proses pembelajaran dan menilai kemampuan siswa dalam menyelesaikan tugas dalam kelompoknya. Aktif membimbing siswa. Selama diskusi berlangsung Guru berkeliling mengawasi, membimbing dan menjelaskan kepada siswa atau kelompok yang memerlukan penjelasan akan temuannya, agar hasil yang dicapai lebih optimal. Selain itu, Guru juga memotivasi siswa agar melakukan diskusi dengan baik. Guru menyuruh salah satu siswa untuk mempresentasikan hasil temuan kelompoknya dan memeriksa serta mengevaluasi dengan baik. Guru memotivasi siswa yang merasa malu untuk maju presentasi hasil temuan.

Adapun prosentase hasil observasi dalam pelaksanaan percobaan pada siklus I dapat dilihat dari tabel 3 bawah ini. Perhitungan prosentase keberhasilan siklus I di bawah ini diskusikan juga dengan teman sejawat.

Tabel 1 Prosentase Hasil Observasi Siklus I

\begin{tabular}{|l|l|l|}
\hline No & Kegiatan Siswa & Prosentase \\
\hline 1 & Kelengkapan menyiapkan alat dan bahan percobaan & $30 \%$ \\
\hline 2 & Keruntutan langkah-langkah dalam pelaksanaan kegiatan percobaan & $52 \%$ \\
\hline 3 & Keaktifan siswa selama melaksanakan kegiatan percobaan & $57 \%$ \\
\hline 4 & Keaktifan siswa dalam mengutarakan pendapat saat berdiskusi & $43 \%$ \\
\hline 5 & Kesimpulan akhir sesuai percobaan & $46 \%$ \\
\hline
\end{tabular}

Hasil post test pada siklus pertama dapat menjadi perhitungan persentase peningkatan prestasi prestasi belajar siswa. Dengan acuan penilaian tetap berdasarkan nilai KKM yang telah ditetapkan yaitu paling sedikit siswa memperoleh nilai 70. Adapun rekapitulasi hasil test siklus I adalah sebagai berikut:

Tabel 2 Hasil Post Test Siklus Pertama

\begin{tabular}{|l|l|l|}
\hline No & Deskripsi & Nilai \\
\hline 1 & Jumlah Nilai & 810 \\
\hline 2 & Rata-rata Hasil Post Test & 73,6 \\
\hline 3 & Jumlah siswa yang mendapat nilai diatas KKM (70) & 10 \\
\hline 4 & Presentase siswa yang mendapat nilai diatas KKM (70) & $41,7 \%$ \\
\hline 5 & Jumlah siswa yang mendapat nilai dibawah KKM (70 & 14 \\
\hline 6 & Presentase siswa yang mendapat nilai dibawah KKM (70) & $58,3 \%$ \\
\hline
\end{tabular}

Nilai rata-rata hasil post test, dapat dihitung dari :

$\dot{X}=\frac{\sum X}{\sum N}$, Jadi $\dot{X}=\frac{810}{24}=73,6$ 
Nilai KKM $=70$. Jadi sudah ada peningkatan prestasi belajar, namun hanya sedikit.

Rumus Ketuntasan Individu (prestasi belajar siswa) = $\frac{\sum \text { siswa yang mendapat nilai } \geq 70}{\sum \text { siswa }} \times 100 \%$

Jadi, Ketuntasan Individu (prestasi belajar siswa) $=\frac{10}{24} \times 100 \%=41,7 \%$

Masing kurang dari indicator pencapaian siklus I sebesar $85 \%$ atau lebih. Maka dilanjutkan percobaan pembelajaran dengan Metode think pair share pada siklus II.

Tabel berikut adalah daftar frekuensi nilai post test siklus I Pendidikan Kewarganegaraan peran serta dalam pemilihan organisasi di sekolah dengan soal pengerjaan siswa kelas VA SD Negeri 2 Banyuurip Kalidawir Tulungagung setelah pembelajaran menggunakan Metode think pair share, dengan nilai minimal KKM sebesar 70:

Tabel 3 Daftar Nilai Ulangan Harian Siklus I

\begin{tabular}{|l|l|l|}
\hline Nilai & Frekuensi & Prosentase \\
\hline $0-40$ & 0 & $0.0 \%$ \\
\hline $41-69$ & 8 & $33,3 \%$ \\
\hline $70-100$ & 16 & $66,7 \%$ \\
\hline Jumlah & 24 & $100 \%$ \\
\hline
\end{tabular}

Dari tabel diatas dapat kita lihat terdapat 8 siswa atau 33,3\% yang mendapat nilai antara $41-69$, dan 16 siswa atau $66,7 \%$ yang mendapat nilai antara 70 - 100. Dengan ketentuan nilai KKM 70, dapat disimpulkan jika pencapaian prestasi nilai 70 - 100, maka prestasi belajar siswa telah meningkat dari $41,7 \%$ menjadi $66,7 \%$. Namun karena belum mencapai target indicator pencapaian siklus I sebesar $85 \%$ atau lebih, maka akan dilanjutkan ke Siklus II.

Selain itu, dari proses wawancara diperoleh kesimpulan bahwa beberapa siswa menjadi bersemangat dalam belajar Pendidikan Kewarganegaraan, karena pelaksanaan kegiatan belajar Pendidikan Kewarganegaraan dengan Metode think pair share ini dilaksanakan dengan langsung secara mandiri oleh siswa, dan melaksanakan kegiatan bersama kelompok sehingga lebih ringan. Meskipun masih terdapat kendala-kendala seperti yang telah diuraikan dalam laporan observasi.

\section{Siklus II}

\section{Observasi Kegiatan Siswa}

Sama dengan pelaksanaan observasi pada siklus I, kegiatan observasi dilaksanakan saat proses pembelajaran Pendidikan Kewarganegaraan berlangsung. Kegiatan observasi difokuskan pada pelaksanaan pembelajaran. Pertama, dalam kegiatan ini, Guru mengamati jalannya pembelajaran.

Kedua, Guru mengamati langkah-langkah kegiatan siswa ketika melaksanakan percobaan, sudah sesuaikah langkah yang ditempuh siswa dengan langkah-langkah yang tertera dalam lembar kegiatan. Pada siklus II ini Guru telah memberi bimbingan kepada kelompok-kelompok yang mengalami kesulitan pada siklus I untuk menerapkan langkah-langkah yang tertera dalam lembar kegiatan. 
Hasilnya, semua kelompok dapat memahami langkah-langkah pembelajaran dan dapat menjalankan kegiatan sesuai dengan lembar kegiatan yang tersedia. Ketiga, Guru mengamati keaktifan siswa saat melaksanakan percobaan, Pada siklus II ini kebanyakan siswa telah aktif dalam mengikuti pelaksanaan percobaan, hanya terdapat 3-4 siswa yang terlihat mengobrol ataupun berdiam diri.

Pengamatan selanjutnya, Guru mengamati bagaimana keaktifan siswa ketika berdiskusi untuk menarik simpulan. Pengamatan yang paling akhir adalah bagaimana kesimpulan hasil diskusi siswa, apakah sesuai dengan hasil pelaksanaan percobaan atau tidak. Dari pengamatan yang terakhir ini, dengan adanya reward yang diberikan oleh Guru, semua kelompok berani mempresentasikan hasil temuannya, dan hanya terdapat 3-4 siswa saja yang kurang aktif dalam diskusi.

Dari uraian di atas dapat disimpulkan hasil observasi dari siklus II antara lain: Sebagian besar siswa mengerjakan tugas secara berkelompok dengan antusias. Sebagian besar siswa terlibat aktif dalam pembelajaran dengan menggunakan Metode think pair share dengan cara siklus II. Hampir semua siswa sudah memperhatikan penjelasan Guru. Hanya ada 3-4 siswa yang tidak memperhatikan, mereka justru mengajak bicara dengan teman sebangkunya ataupun melamun. Dengan adanya reward, terdapat sebagian besar siswa yang ikut ambil bagian dalam diskusi kelompok. Sebagian kecil siswa masing tampak saling berbincang dengan teman duduknya ataupun melamun. Diskusi dilakukan dengan baik. 3 (tiga) kelompok yang terbagi, mereka sudah dapat menyelesaikan Lembar Kegiatan dengan tepat waktu. Siswa yang terlihat lemah pada siklus I, lebih banyak mendapat perhatian dan bimbingan dari Guru.Dengan adanya reward, 3 (tiga) kelompok sudah berani mempresentasikan hasil temuan kelompoknya. Mereka tampak detail dalam mempresentasikan hasil temuannya.

Metode pelaksanan pembelajaran Metode think pair share dengan mempraktekkan tata cara pemilihan pengurus kelas. Bersama-sama dengan kelompok, siswa saling berdiskusi mendeskripsikan kegiatan tersebut dalam bentuk rangkuman terlihat lebih efektif. Sewaktu presentasi hasil kelompok dilakukan, dengan adanya reward, hampir semua siswa mengajukan pertanyaan, hanya terdapat 3-4 siswa yang masih malu mengajukan pertanyaan. Sehingga dapat disimpulkan bahwa penerapan Metode think pair share siklus II ini maksimal dalam menyerap konsep yang diajarkan.Hasil post test menjukkan prestasi belajar siswa pun meningkat.

\section{Observasi Kegiatan Guru}

Pergantian pelaksanaan pembelajaran Metode think pair share dilaksanakan dengan baik. Melaksanakan pembelajaran sesuai dengan rencana pembelajaran yang telah disusun. Guru membuka pelajaran dengan baik, mengabsen siswa dan menyampaikan tujuan pembelajaran. Menjelaskan kembali tentang pembelajaran dengan Metode think pair share. Karena telah diperkenalkan sebelumnya, maka siswa telah memahami konsep dengan baik. Mengamati jalannya proses pembelajaran dan menilai kemampuan siswa dalam menyelesaikan tugas dalam kelompoknya. Aktif membimbing siswa. Selama diskusi berlangsung Guru berkeliling mengawasi, membimbing dan menjelaskan kepada siswa atau kelompok yang memerlukan penjelasan akan temuannya, agar hasil yang dicapai lebih optimal. Selain itu, Guru juga memotivasi siswa agar 
melakukan diskusi lebih baik lagi dan memberikan reward bagi mereka yang aktif. Guru menyuruh salah satu siswa untuk mempresentasikan hasil temuan kelompoknya dan memeriksa serta mengevaluasi dengan baik. Guru memotivasi siswa yang merasa malu untuk maju presentasi hasil temuan dan memberikan reward bagi mereka yang berani tampil presentasi.

Adapun prosentase hasil observasi dalam pelaksanaan percobaan pada siklus II dapat dilihat dari tabel bawah ini. Perhitungan prosentase keberhasilan siklus II di bawah ini diskusikan juga dengan teman sejawat.

Tabel 4 Prosentase Hasil Observasi Siklus II

\begin{tabular}{|l|l|l|}
\hline No & Kegiatan Siswa & Prosentase \\
\hline 1 & Kelengkapan menyiapkan alat dan bahan percobaan & $90 \%$ \\
\hline 2 & $\begin{array}{l}\text { Keruntutan langkah-langkah dalam pelaksanaan kegiatan } \\
\text { percobaan }\end{array}$ & $85 \%$ \\
\hline 3 & Keaktifan siswa selama melaksanakan kegiatan percobaan & $89 \%$ \\
\hline 4 & Keaktifan siswa dalam mengutarakan pendapat saat berdiskusi & $87 \%$ \\
\hline 5 & Kesimpulan akhir sesuai percobaan & $88 \%$ \\
\hline
\end{tabular}

Hasil post test pada siklus kedua dapat menjadi perhitungan persentase peningkatan prestasi belajar siswa. Dengan acuan penilaian tetap berdasarkan nilai KKM yang telah ditetapkan yaitu paling sedikit siswa memperoleh nilai 70 . Adapun rekapitulasi hasil test siklus II adalah sebagai berikut:

Tabel 5 Hasil Post Test Siklus Kedua

\begin{tabular}{|l|l|l|}
\hline No & Deskripsi & Nilai \\
\hline 1 & Jumlah Nilai & 930 \\
\hline 2 & Rata-rata Hasil Post Test & 84,5 \\
\hline 3 & Jumlah siswa yang mendapat nilai diatas KKM (70) & 23 \\
\hline 4 & Presentase siswa yang mendapat nilai diatas KKM (70) & $90,9 \%$ \\
\hline 5 & Jumlah siswa yang mendapat nilai dibawah KKM (70 & 1 \\
\hline 6 & Presentase siswa yang mendapat nilai dibawah KKM (70) & $9,1 \%$ \\
\hline
\end{tabular}

Nilai rata-rata hasil post test, dapat dihitung dari :

$\dot{X}=\frac{\sum X}{\sum N}$, Jadi $\dot{X}=\frac{2028}{24}=84,5$

Nilai KKM $=70$. Jadi sudah ada peningkatan prestasi belajar yang signifikan.

Rumus Ketuntasan Individu (prestasi belajar siswa) $=$

$\frac{\sum \text { siswa yang mendapat nillai } \geq 70}{\text { Esiswa }} \times 100 \%$

Jadi, Ketuntasan Individu (prestasi belajar siswa) $=\frac{1}{24} \times 100 \%=95,8 \%$

Telah mencapai indicator pencapaian siklus II sebesar $85 \%$ atau lebih. Maka tidak perlu dilanjutkan percobaan pembelajaran dengan Metode think pair share pada siklus III.

Tabel berikut adalah daftar frekuensi nilai post test siklus II Pendidikan Kewarganegaraan dengan peran serta dalam pemilihan organisasi di sekolah siswa kelas VA SD Negeri 2 Banyuurip Kalidawir Tulungagung setelah pembelajaran 
menggunakan Metode think pair share siklus II, dengan nilai minimal KKM sebesar 70:

Tabel 6 Daftar Nilai Ulangan Harian Siklus II

\begin{tabular}{|l|l|l|}
\hline Nilai & Frekuensi & Prosentase \\
\hline $0-40$ & 0 & $0.0 \%$ \\
\hline $41-69$ & 1 & $4,2 \%$ \\
\hline $70-100$ & 23 & $95,8 \%$ \\
\hline Jumlah & 24 & $100 \%$ \\
\hline
\end{tabular}

Dari tabel diatas dapat kita lihat terdapat 1 siswa atau 4,2\% yang mendapat nilai antara $41-69$, dan 23 siswa atau 95,8\% yang mendapat nilai antara 70 - 100. Dengan ketentuan nilai KKM 70, dapat disimpulkan jika pencapaian prestasi nilai $70-100$, maka prestasi belajar siswa telah meningkat dari $66,7 \%$ menjadi $95,8 \%$. Dengan $85 \%$ maka telah tercapai indicator pencapaian siklus II sebesar yang $85 \%$ atau lebih, maka tidak perlu dilanjutkan ke Siklus III.

Selain itu, dari proses wawancara diperoleh kesimpulan bahwa beberapa siswa menjadi bersemangat dalam belajar Pendidikan Kewarganegaraan, karena pelaksanaan kegiatan belajar Pendidikan Kewarganegaraan yang menggunakan Metode think pair share ini dilaksanakan dengan secara baik bersama kelompok menjadikan mereka lebih rileks dan ringan dalam mengerjakan laporan kegiatan. Meskipun masih terdapat kendala-kendala seperti yang telah diuraikan dalam laporan observasi.

\section{PEMBAHASAN}

Berdasarkan hasil pelaksanaan pada siklus I, II dapat dinyatakan bahwa terjadi peningkatan kualitas pembelajaran yang tampak dan perolehan hasil evaluasi dan keaktifan siswa. Dari tabel 4.2 dan gambar 4.2 siklus I hasil observasi menunjukkan, prosentase keberhasilan kelengkapan menyiapkan alat dan bahan percobaan 30\%, prosentase keruntutan langkah-langkah yang ditempuh dalam pelaksanaan percobaan 52\%, prosentase keaktifan siswa dalam melaksanakan kegiatan percobaan $57 \%$, prosentase keaktifan siswa dalam mengutarakan pendapat saat berdiskusi $43 \%$ dan prosentase hasil penarikan kesimpulan akhir sesuai percobaan $46 \%$.

Berdasarkan tabel 4.5 dan gambar 4.5 siklus II hasil obserVAasi menunjukkan, prosentase keberhasilan metode kelengkapan menyiapkan alat dan bahan percobaan siswa yang disiapkan 90\%, prosentase keruntutan langkahlangkah yang ditempuh dalam pelaksanaan percobaan $85 \%$, prosentase keaktifan siswa dalam melaksanakan kegiatan percobaan $89 \%$, prosentase keaktifan siswa dalam mengutarakan pendapat saat berdiskusi $87 \%$ dan prosentase hasil penarikan kesimpulan akhir sesuai percobaan $88 \%$.

Dari daftar nilai (lihat lampiran) dapat kita lihat adanya prosentase kenaikan nilai Pendidikan Kewarganegaraan mulai dari kondisi awal pra tindakan, diketahui baru 10 siswa atau 41,7\% yang mengalami ketuntasan belajar dan mendapatkan nilai sesuai dengan KKM. Hasil evaluasi siklus I menunjukkan baru 14 siswa atau 66,7\% yang mengalami ketuntasan belajar dan mendapat nilai sama dengan atau di atas KKM yaitu 70. Hal itu menunjukkan bahwa pelaksanaan siklus I belum mencapai keberhasilan, karena indicator pencapaian adalah sebesar

89 BRILIANT: Jurnal Riset dan Konseptual Volume 3 Nomor 1, Februari 2018 
$85 \%$ atau lebih. Siklus II menunjukkan ada 23 siswa atau 95,8\% dari 24 siswa yang mengalami ketuntasan belajar. Sehingga peneliti menyimpulkan bahwa pada siklus II ini peneliti telah mencapai keberhasilan dari penelitian tindakan kelas yang telah dilakukan.

Ketika peneliti melaksanakan siklus I, peneliti mengalami berbagai kendala antara lain beberapa siswa tidak membantu teman kelompoknya dan hanya bermain-main. Masih ada kelompok yang bingung dalam mengikuti langkah-langkah yang tertera dalam lembar kegiatan. Masih ada beberapa siswa yang belum aktif dalam pelaksanaan percobaan. Ketika pelaksanaan diskusi, ada beberapa siswa yang tidak aktif menyampaikan pendapatnya. Dalam menyimpulkan hasil percobaan, terdapat 2 (dua) kelompok yang malu untuk presentasi, dan hanya terdapat 3 (tiga) siswa yang mengajukan pertanyaan.

Peneliti kemudian melaksanakan siklus II sebagai perbaikan siklus I, sebelum pelaksanaan siklus II ini peneliti mengganti rencana pembelajaran Metode think pair share baru yaitu dengan mempraktekkan tata cara pemilihan pengurus kelas. Bersama-sama dengan kelompok, siswa saling berdiskusi mendeskripsikan kegiatan tersebut dalam bentuk rangkuman.. Dalam pelaksanaan percobaan, peneliti senantiasa memberi bimbingan untuk siswanya dalam melaksanakan langkah-langkah sesuai lembar kegiatan. Peneliti pun memberi bimbingan siswa saat berdiskusi untuk menarik kesimpulan. Dengan adanya motivasi guru berupa reward, siswa telah terlihat aktif dalam kegiatan pembelajaran dalam melaksanakan percobaan, presentasi di depan kelas dan berdiskusi menarik kesimpulan. Meskipun ada kendala yaitu siswa tampak gaduh saat melaksanakan kegiatan praktek pemilihan pengurus kelas, namun dengan hasil prestasi belajar yang dicapai dapat disimpulkan bahwa penelitian tindakan kelas dari siklus II ini telah berhasil.

\section{KESIMPULAN}

Berdasarkan hasil penelitian tindakan kelas yang telah dilaksanakan dalam 2 siklus dengan menerapkan Metode think pair share dalam pembelajaran Pendidikan Kewarganegaraan pada siswa kelas VA SD Negeri 2 Banyuurip Kalidawir Tulungagung, dapat dibuat kesimpulan sebagai berikut: Penerapan Metode think pair share dapat meningkatkan prestasi belajar Pendidikan Kewarganegaraan siswa kelas VA SD Negeri 2 Banyuurip Kalidawir Tulungagung.. Adanya perubahan kenaikan prosentase dalam menyiapkan alat dan bahan, keruntutan langkah-langkah siswa dalam melaksanakan percobaan, keaktifan siswa dalam melaksanakan kegiatan percobaan, keaktifan siswa ketika berdiskusi dan hasil akhir atau simpulan.

\section{SARAN}

Berdasarkan hasil penelitian, maka ada beberapa saran yang dapat dipergunakan sebagai bahan pertimbangan dan sebagai bahan uraian penutup penelitian tindakan kelas ini, antara lain: (1) Bagi Guru, Guru juga harus memahami dan memvariasikan metode yang sesuai materi yang dapat digunakan dalam proses pembelajaran, sehingga siswa tidak merasa bosan. (2) Bagi Siswa, selalu mengerjakan tugas-tugas yang diberikan guru dan meningkatkan usaha belajar sehingga dapat memperoleh prestasi yang diharapkan. (3) Bagi Sekolah, Hendaknya mengupayakan pengadaan berbagai media pembelajaran Pendidikan 
Kewarganegaraan untuk kelas rendah, baik bantuan maupun swadaya sekolah, sehingga lebih menunjang dalam penanaman konsep-konsep Pendidikan Kewarganegaraan secara lebih nyata sekaligus meningkatkan aktivitas belajar siswa.

\section{DAFTAR RUJUKAN}

Branson, M.S. 1997. The Role of Civic Education. Calabasas: CCE.

Buchori M. 1997. Psikologi Pendidikan 3. Bandung: Jeanmars.

Ibrahim, dkk. 2000. Pembelajaran Kooperatif. Surabaya: Unesa Press

Lie, Anita. 2002. Cooperatif Learning. Jakarta: PT. Gramedia Widisarana Indonesia.

Sudjana, N. 1989. Penilaian Hasil Proses Belajar Mengajar. Bandung: Remaja Rosdakarya.

Sudjana, N., \& Ibrahim. 1989. Penelitian dan Penilaian Pendidikan. Bandung : Sinar Baru.

Oemar Hamalik. 1999. Proses Belajar Mengajar. Jakarta : Bumi Aksara.

Winataputra, U.S. \& Budimansyah. 2007. Civic Education, Konteks, Landasan, Bahan Ajar dan Kultur Kelas. Bandung: UPI. 